\title{
EFFECT OF SEVERE PLASTIC DEFORMATION ON RADIATION HARDENING OF T91 FERRITIC-MARTENSITIC STEEL
}

\author{
V.N. Voyevodin ${ }^{1,2}$, G.D. Tolstolutskaya ${ }^{1}$, S.A. Karpov ${ }^{1}$, A.N. Velikodnyi ${ }^{1}$, M.A. Tikhonovsky ${ }^{1}$, \\ A.S. Kalchenko ${ }^{1}$, G.N. Tolmachova ${ }^{1}$, R.L. Vasilenko ${ }^{1}$, I.E. Kopanets \\ ${ }^{1}$ National Science Center “Kharkov Institute of Physics and Technology”, Kharkiv, Ukraine; \\ ${ }^{2}$ V.N. Karazin Kharkiv National University, Kharkiv, Ukraine \\ E-mail:voyev@kipt.kharkov.ua
}

Effect of thermomechanical treatment on radiation hardening behavior in T91 ferritic-martensitic steel was evaluated. An applying of severe plastic deformation (SPD) by the "upsetting-extrusion" method and subsequent heat treatment led to a considerable grain refinement, crushing of martensite lamellas, reduction of MX carbides size and their more uniform distribution. Nanoindentation measurements of SPD-modified steel revealed a 1.4-fold increase in the hardness relative to the initial steel. Irradiation response of modified steel was examined after 1.4 $\mathrm{MeV} \mathrm{Ar}^{+}$ion irradiations in the dose range of $10 \ldots 45$ displacements per atom (dpa) at room temperature and $460{ }^{\circ} \mathrm{C}$. Microstructure characterization was performed by means of transmission electron microscopy (TEM). It was found that dislocation loops and nano-sized argon bubbles dominated the damage microstructure after ion irradiation. The effects of SPD-induced transformations as well as nano-bubbles formation are discussed regarding to the hardening phenomenon observed in irradiated steel.

\section{INTRODUCTION}

Ferritic-martensitic steels are prime candidate materials for structural components in high-dose nuclear power applications. Compared to austenitic stainless steels, F-M alloys are considered to be more resistant to neutron irradiation, from the viewpoint of radiation swelling. In addition, these steels also have higher thermal conductivity, lower coefficients of thermal expansion, good creep characteristics, high strength at elevated temperatures, and lower cost [1]. For F-M steels with a high chromium content, the most significant radiation effect is the degradation of mechanical properties due to radiation hardening and embrittlement. Since noticeable hardening is observed at the lowest radiation dose of about $0.01 \mathrm{dpa}$ [2], understanding of the microstructural evolution and its influence on the reduction of mechanical properties is of high importance.

Significant improvement of mechanical properties is anticipated through the formation of an ultra-finegrained or nanostructured state in the steel. The formation of such a microstructure is possible by using mechanical-heat treatment utilizing severe plastic deformation, which can be carried out by various methods $[3,4]$. It is expected that the radiation tolerance of the material after severe plastic deformation will be enhanced.

Irradiation of materials with accelerated ions to simulate neutron reactor irradiation is a common practice due to the short timescales for achieving relatively high damage levels and the absence of induced radioactivity.

However, ion irradiation has a significant drawback - a small depth of the damaged layer, which complicates the study of mechanical properties. The solution of this problem is possible by using of nanoindentation, transmission and scanning electron microscopy - small-scale methods that can be used to study changes in the microstructure and mechanical properties under irradiation in small volumes.

Recently, the effect of irradiation on the swelling behavior in the promising T91-M ferritic-martensitic steel after severe plastic deformation (SPD) and heat treatment at $550{ }^{\circ} \mathrm{C}$ for $25 \mathrm{~h}$ was investigated [5].

The aim of the present work is to determine the dose dependent hardness and evolution of microstructure of T91 steel after SPD by the multiple "upsettingextrusion" method followed by heat treatment at $600{ }^{\circ} \mathrm{C}$ and irradiation with accelerated argon ions up to $45 \mathrm{dpa}$ at temperatures 20 and $460{ }^{\circ} \mathrm{C}$.

\section{MATERIAL AND EXPERIMENTAL DETAILS}

T91-M steel manufactured by INDUSTELL, Belgium (melting: 504/3, heat: 82566-4) was supplied in the form of a $40 \mathrm{~mm}$ thick plate obtained by hot rolling followed by heat treatment. The heat treatment includes normalization at $1040{ }^{\circ} \mathrm{C}$ for $30 \mathrm{~min}$, followed by air cooling and then tempering at $730{ }^{\circ} \mathrm{C}$ for $60 \mathrm{~min}$ with air cooling to room temperature (the so-called N\&T state). The chemical composition of T91-M steel is shown in Table.

The chemical composition of T91-M (wt.\%)

\begin{tabular}{|c|c|c|c|c|c|c|c|c|}
\hline Fe (bulk) & $\mathrm{Cr}$ & $\mathrm{Mo}$ & $\mathrm{Mn}$ & $\mathrm{Si}$ & $\mathrm{V}$ & $\mathrm{Ni}$ & $\mathrm{Nb}$ & $\mathrm{Cu}$ \\
\hline $\mathrm{T} 91$ & 8.76 & 0.862 & 0.597 & 0.317 & 0.186 & 0.099 & 0.073 & 0.054 \\
\hline $\mathrm{Al}$ & $\mathrm{C}$ & $\mathrm{N}$ & $\mathrm{P}$ & $\mathrm{S}$ & $\mathrm{Sn}$ & $\mathrm{B}$ & $\mathrm{Co}$ & $\mathrm{As}$ \\
\hline 0.021 & 0.088 & 0.003 & 0.019 & 0.0006 & 0.005 & 0.0001 & 0.019 & 0.007 \\
\hline
\end{tabular}


In the present study the multi-cycle "upsettingextrusion" method was chosen to carry out the SPD. The method was developed in NSC KIPT and it has proved itself both in laboratory research and in the industrial production of a number of materials with high characteristics $[3,6]$. This method consists in multiple reiterations of operations of upsetting and extrusion on a hydraulic press DB 2432 with a force of 160 tf. The method is described in more detail in [4].

The deformation was carried out in the two-phase region of stability of austenite and ferrite at a temperature of $875^{\circ} \mathrm{C}$, which is below the $\mathrm{Ac}_{3}$ point by $30 \ldots 35^{\circ} \mathrm{C}$. Samples with a $20 \mathrm{~mm}$ diameter and a $60 \mathrm{~mm}$ height were subjected to upsetting to a diameter $30 \mathrm{~mm}$ and then again extruded to a diameter of $20 \mathrm{~mm}$.

The true deformation for 1 cycle of upsettingextrusion was $e=1.8$. Three upsetting-extrusion cycles were carried out (total true strain was $e=5.4$ ). To stabilize the microstructure formed as a result of SPD, heat treatments were performed at $600{ }^{\circ} \mathrm{C}$ for $25 \mathrm{~h}$.

Samples were irradiated with $1.4 \mathrm{MeV}$ argon ions in a dose range of $10 \ldots 45 \mathrm{dpa}$. All irradiations were carried out with accelerating-measuring system "ESU-2" [7], which contain Van de Graaf accelerator. The irradiations were performed at temperatures 20 and $460{ }^{\circ} \mathrm{C}$.

Nanohardness was measured by Nanoindenter G200 with a Berkovich type indentation tip. Each sample was applied at least 20 prints at a distance of $35 \mu \mathrm{m}$ from each other. Nominal maximum displacement of $2000 \mathrm{~nm}$ was used for all measurements on unirradiated and ion-irradiated steel [8]. The methodology of Oliver and Pharr was used to find the hardness [9].

For transmission studies, plates of $0.3 \mathrm{~mm}$ thick were cut out using the electrospark method, which were mechanically thinned to a thickness of $0.22 \mathrm{~mm}$, and then electropolished. To obtain a hole the thickness of the samples was reduced by standard jet electropolishing in a Tenupol installation in an electrolyte of $80 \% \mathrm{C}_{2} \mathrm{H}_{5} \mathrm{OH}, 10 \% \mathrm{HClO}_{4}, 10 \% \mathrm{C}_{3} \mathrm{H}_{8} \mathrm{O}_{3}$ at a voltage of $70 \mathrm{~V}$ at room temperature. TEM in kinematic bright-field mode was primarily used to characterize radiation-induced structures. To remove a specified depth layer of material from irradiated side of the sample the electro-pulse technique was used and then TEM studies were carried out [10]. Secondary electron images produced in SEM were used for investigations of as-received and irradiated specimens in regions surrounding indents.

\section{RESULTS AND DISCUSSIONS}

The microstructure of as-received T91 steel (hereinafter sample code T91-M) represents the tempered martensite structure with the occurrence of boundaries of former austenite grains and subgrains (Fig. 1).

These boundaries are decorated with precipitates of $\mathrm{M}_{23} \mathrm{C}_{6}$ carbides. The average size of the former austenite grains is $\sim 20 \mu \mathrm{m}$, and the average size of subgrains is $\approx 8 \mu \mathrm{m}$. Martensite lamellas with a transverse size of $0.25 \ldots 0.5 \mu \mathrm{m}$ are observed inside the former austenite grains. In additions, a significant number of small precipitates of $\leq 50 \mathrm{~nm}$ in size, which are usually referred to as MX-type phases is also observed.

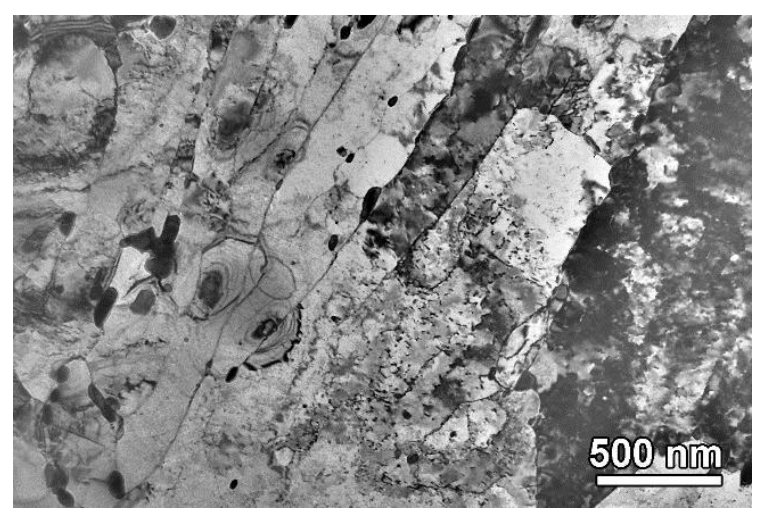

Fig. 1. Microstructure of as-received T91-M steel

An applying of SPD by the "upsetting-extrusion" method led to the development of a broken martensite type structure and to an effective decrease of the average grain size from $8 \mu \mathrm{m}$ in the as-received state to $100 \mathrm{~nm}$ after SPD. After heat treatment at $600{ }^{\circ} \mathrm{C}$ for $25 \mathrm{~h}$ (hereinafter, sample code T91-MSPD), sufficiently large grains of typical "ferritic" morphology have formed (Fig. 2), which appear to be the result of recrystallization of fine grains of final austenite or finegrained areas of "broken" martensite. "Broken" martensite in some zones is transformed into a more "classic" one as a result of the enlargement of martensite lamellas with the average grain size increasing up to $210 \mathrm{~nm}$. The average size and density of $\mathrm{M}_{23} \mathrm{C}_{6}$ precipitates is $120 \mathrm{~nm}$, and $4.2 \cdot 10^{19} \mathrm{~m}^{-3}$, respectively. Carbides of the MX type having the size of $\leq 24 \mathrm{~nm}$ and density of $2.6 \cdot 10^{20} \mathrm{~m}^{-3}$ are more evenly distributed in the grains. TEM observation of unirradiated T91-MSPD sample is represented in Fig. 2.

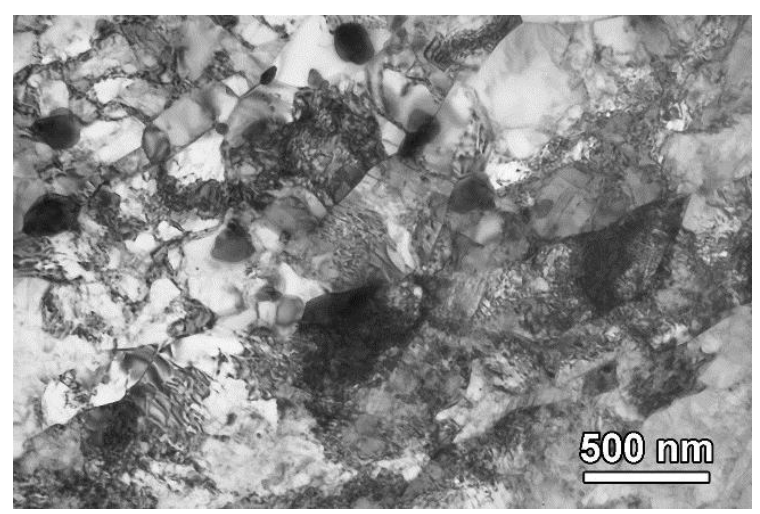

Fig. 2. Microstructure of T91-MSPD

Samples of T91-MSPD were irradiated with $1.4 \mathrm{MeV}$ argon ions to doses of $(0.3 \ldots 1) \cdot 10^{17} \mathrm{~cm}^{-2}$. The average damage level of $10 \ldots 45 \mathrm{dpa}$ over the whole projective ranges of Ar ions instead of the peak damage level was used. The depth distributions of Ar atoms concentration and produced by irradiation damage are shown in Fig. 3. 


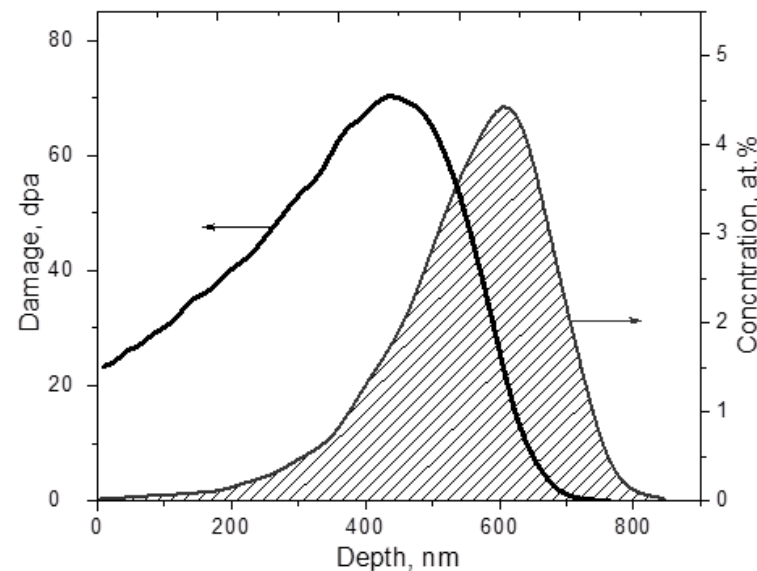

Fig. 3. Calculated profiles of damage and concentration of $1.4 \mathrm{MeV}$ Ar ions implanted in T91-M steel to a dose

$$
\text { of } 1 \cdot 10^{17} \mathrm{~cm}^{-2}
$$

Charged particle implantations in this study were simulated using SRIM. Following the recommendations of Stoller et al. [11], the damage energy (the kinetic energy available for creating atomic displacements [12]) was calculated, and subsequently the dpa values via the NRT equation were obtained [13].

Fig. 4 shows the nanohardness $(H)$ as a function of the indenter displacement $(h)$ for unirradiated and irradiated to $10 \mathrm{dpa}$ sample of T91-MSPD. Irradiation with $\mathrm{Ar}$ ions up to a dose of $10 \mathrm{dpa}$ at $460{ }^{\circ} \mathrm{C}$ leads to an increase in nanohardness.

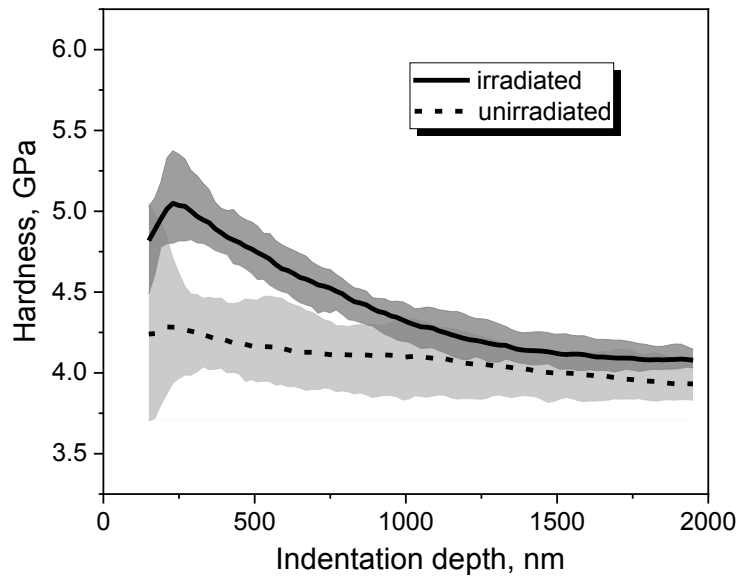

Fig. 4. Average nanohardness values as a function of indentation depth for unirradiated and irradiated to 10 dpa at $460{ }^{\circ} \mathrm{C}$ sample of T91-MSPD

For all samples in the first $150 \mathrm{~nm}$, there is a significant scatter in the data through indenter tip artifacts and surface preparation effects. Therefore, for all samples, data for the first $150 \mathrm{~nm}$ will be ignored in the rest of the analysis.

By redrawing the hardness profile in terms of NixGao plot (squared hardness vs. reciprocal depth), the bulk-equivalent hardness of the ion-irradiated region has been evaluated as $4.75 \mathrm{GPa}$ for irradiation fluence of $10 \mathrm{dpa}$ (Fig. 5). For irradiation doses of 25 and $45 \mathrm{dpa}$ the nanohardness of T91-MSPD was evaluated to be 4.85 and $4.95 \mathrm{GPa}$, respectively.

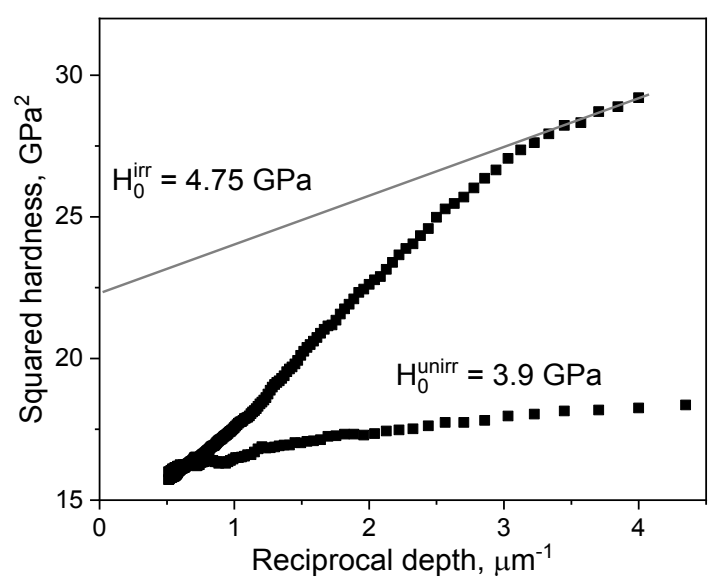

Fig. 5. Nix-Gao plot for unirradiated and argon irradiated T91-MSPD to a dose of 10 dpa at $460^{\circ} \mathrm{C}$

In the case of unirradiated T91-MSPD samples $H_{0}{ }^{\text {unirr }}$ was estimated as $3.9 \mathrm{GPa}$ (see Fig. 5), while for the as-received T91-M samples, this value was $2.98 \mathrm{GPa}$. A significant increase in hardness of T91MSPD appears to be due to the grain refinement, crushing of lamellas, a decrease in MX carbides size and their more uniform distribution.

An important feature of indentation experiments is that the material around the contact area tends to deform upwards (pile-up) or downwards (sink-in) with respect to the indented surface plane $[14,15]$. Depending on the strain-hardening characteristics of the examined material, the area around indents tends to sink in, when the sample is fully annealed and has a high strainhardening potential. On the contrary, the surface around indents tends to pile up, when the indented sample is heavily pre-strained or exhibits a low strain-hardening potential.

In previous work [16], the plastically deformed material has found to form a pile-up around the indent in the unirradiated T91-M (see Fig. 6,a). In the argonirradiated samples (see Fig. 6,b) the pile-up lobes were also formed. In addition, the presence of highly localized slip steps that appear to be curved rather than linear implies the extensive dislocation cross-slip between the existing slip planes.

It should be noted that the pile-up behavior is not only modified by ion implantation. For example, residual stresses can also significantly alter the pile up effect [17].

Indeed, the pile-up unaffected corner-to-corner area which represents the area of the triangle defined by the corners of the hardness impression (Fig. 7,a,c,e) has been observed in unirradiated T91-MSPD samples after applying of SPD by the "upsetting-extrusion" method and subsequent heat treatment. There are no indications of the formation of pile-up lobes or localized slip steps. This fact confirms that the T91-MSPD is heavily prestrained in comparison with as-received T91-M.

The irradiated samples also showed virtual, if any, pile-up effect (see Fig. 7,b,d,f). For this reason, a contact area correction for the pile-up was not attempted. 


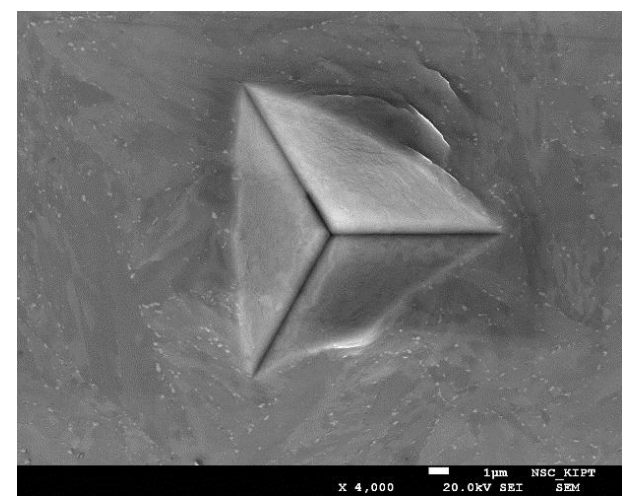

$a$

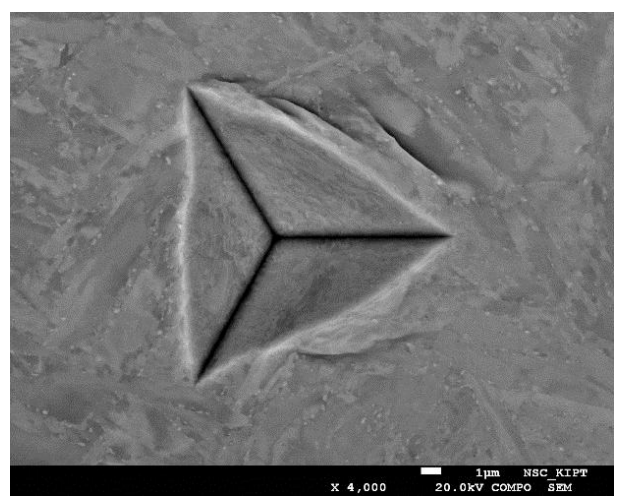

$b$

Fig. 6. SEM images showing deformed regions surrounding indents in un-irradiated (a) and irradiated regions (b) in the T91-M [16]

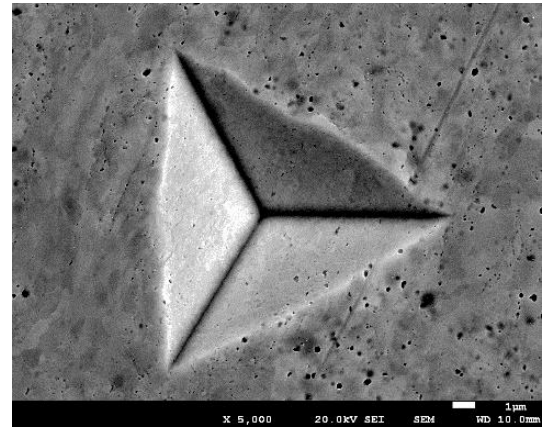

$a$

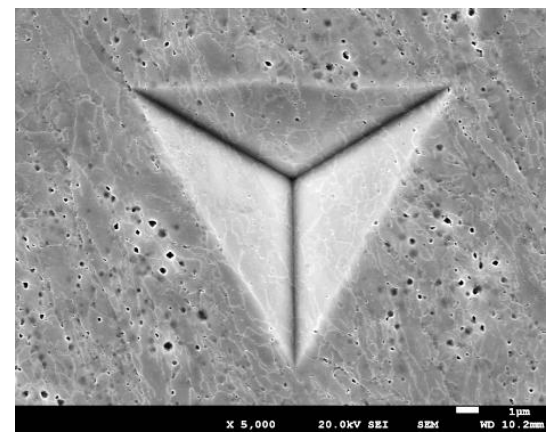

$d$

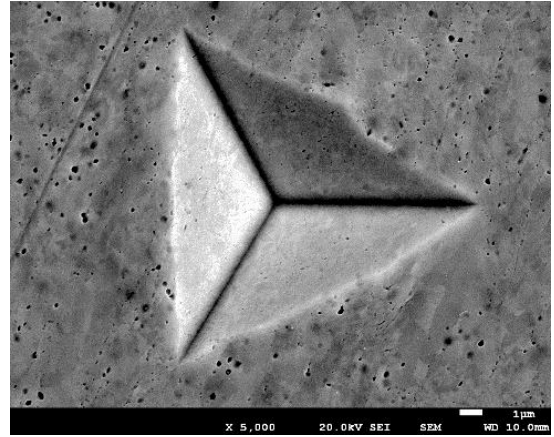

$b$

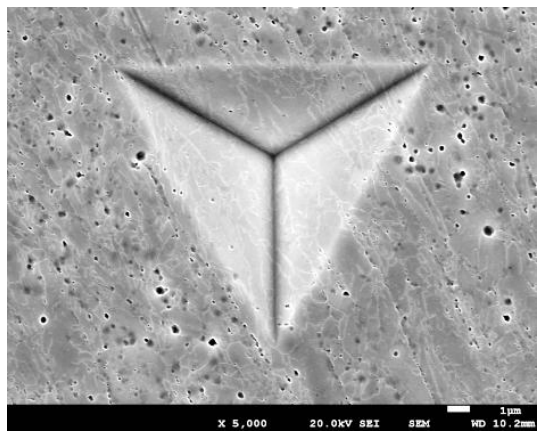

$e$

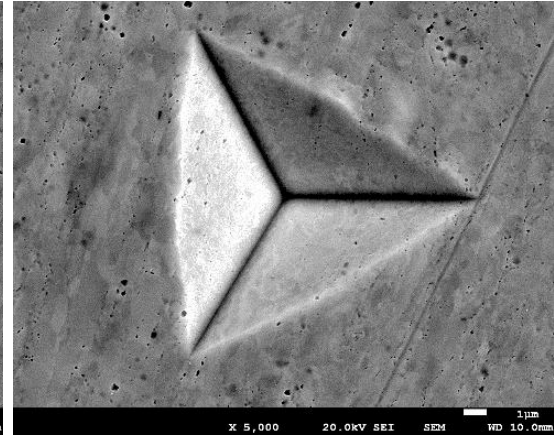

$c$

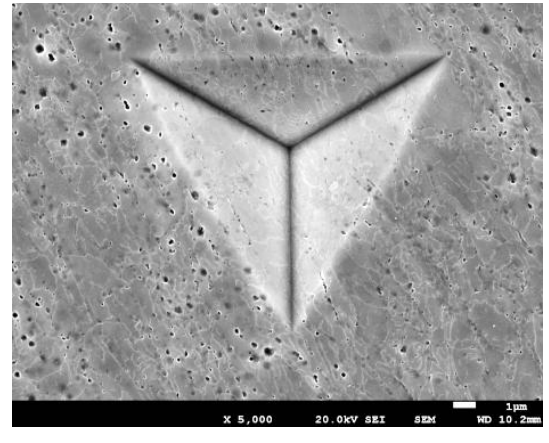

$f$

Fig. 7. SEM images showing areas that surround prints in unirradiated (a, $b, c)$ and irradiated up to $10(d), 25(e)$, and 45 dpa (f) T91-MSPD samples

Although the complexity of T91-MSPD microstructure impedes a detailed analysis of the underlying microscopic mechanism, there are clear indications that the irradiated samples showed considerable changes in microstructure compared to the unirradiated steel sample.

In the region of the first $200 \mathrm{~nm}$, irradiation-induced defects of very small-sized "black spots" and dislocation loops were observed in the microstructure of T91-MSPD samples irradiated at $T_{\text {room}}$. These defects disappeared upon tilting of sample by small degrees, which clearly indicates that these are not precipitates (Fig. 8,a,b).

A high number density of nanoscale white dots, distributed mainly in the depth range of $400 \ldots 600 \mathrm{~nm}$ from the sample surface, was observed in the microstructure of T91-MSPD samples irradiated at $T_{\text {room }}$ (see Fig. 8,c) and $460{ }^{\circ} \mathrm{C}$ (see Fig. 8,d). The distribution of these white dots approximately agrees with the argon concentration profile shown in Fig. 3.
The image in the inset of Fig. 8,c was obtained under overfocus conditions. For the underfocus condition, defects appear as white dots surrounded by black fringes, while for the overfocus condition, the defects are black and the fringes are white, indicating the formation of cavities.

Near spherical shape of nanocavities is characteristic feature for gas bubbles when the surface energy and internal pressure are balanced [18]. Based on these observations, the cavities formed in the present irradiation condition were considered to be Ar-filled bubbles.

Bubble diameters were determined using Image J software as the distance measured between two inside edge of the first dark Fresnel fringe in underfocus conditions. In order to assure the statistical significance of the determined size distributions, a minimum number of 200 bubbles was analyzed for each examined micrograph. Errors in the estimates may occur due to surface oxidation effects, surface roughness, bubble 
placement within the TEM foil, and the Ar content within individual bubbles.

For more accurate determination of cavity density, the TEM sample thickness was determined using a convergent beam electron diffraction (CBED) pattern acquired in the two-beam approximation [19]. The thickness estimation method is based on a comparison of the measured and simulated intensity profiles across the diffraction disc. The method has a fairly good accuracy with a limited number of thickness fringes, which is typical for crystals of small thickness.

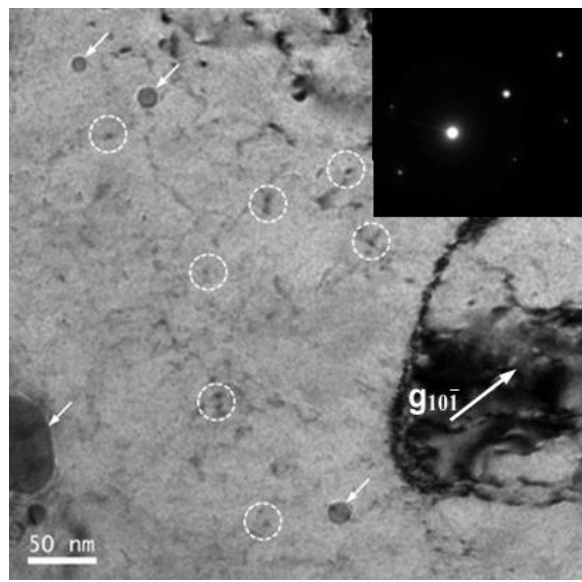

$a$

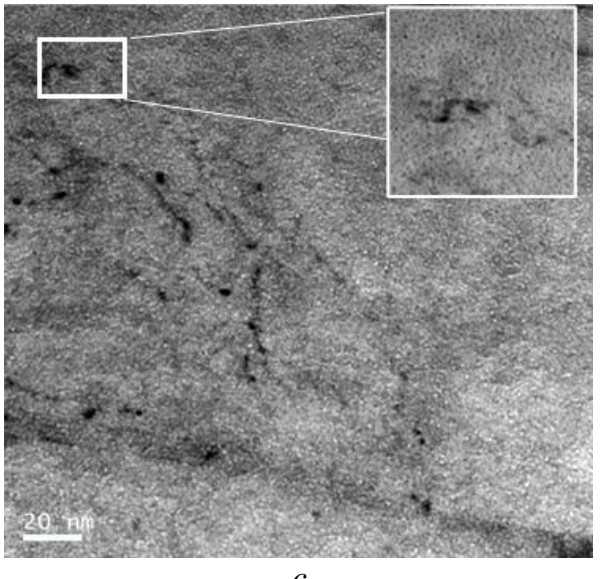

$c$
An average bubble diameter was estimated to be $(0.8 \pm 0.25) \mathrm{nm}$ with a density of $3 \cdot 10^{24} \mathrm{~m}^{-3}$ for irradiation T91-MSPD at $T_{\text {room }}$ up to a dose of $10 \mathrm{dpa}$. For irradiation at $460{ }^{\circ} \mathrm{C}$ up to the same dose the average bubble diameter was $(2.5 \pm 0.5) \mathrm{nm}$ and a density of $1.5 \cdot 10^{24} \mathrm{~m}^{-3}$ in the depth range of $400 \ldots 600 \mathrm{~nm}$.

Today it is believed that defects that become obstacles for moving dislocations at low temperatures are dislocation loops and network dislocations. At intermediate and high temperatures, voids and precipitates become more important and loops less important to strength and hence ductility changes.

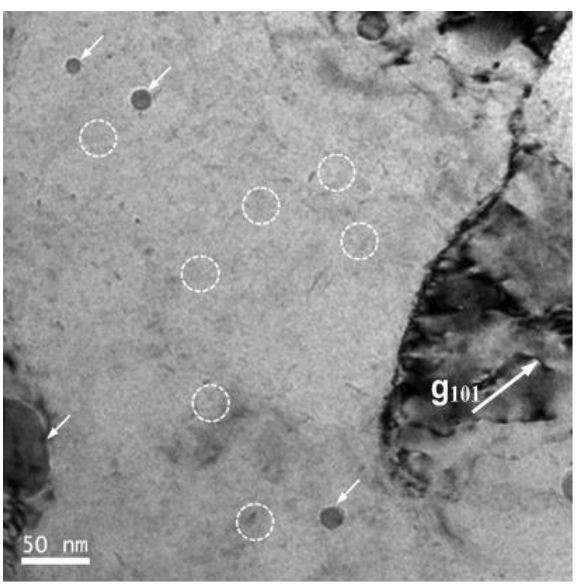

b

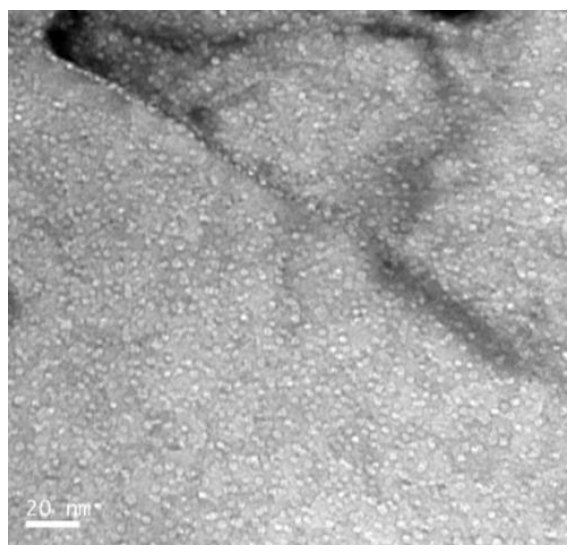

$d$

Fig. 8. Bright-field (BF) images showing the irradiation induced microstructures T91-MSPD irradiated by Ar ions up to 10 dpa at $T_{\text {room }}(a-c)$ and at $460{ }^{\circ} \mathrm{C}(d)$. The image in Fig. 8, a,b was obtained upon tilting of sample by 0 and

2.0 degrees and shows some dislocation loops and precipitates were marked by dotted line circles and arrows,

respectively. [111] zone selected area electron diffraction pattern obtained from the region in Fig. 8,a.

The enlarged micrographs of that in the box of figure $(c)$ obtained under the over-focus condition

To evaluate the efficiency of different types of cavities as obstacles, molecular dynamics simulation was previously used by authors [20] to detail the interaction of an edge dislocation with a $2-\mathrm{nm}$ void or $\mathrm{He}$ bubble in $\mathrm{Fe}$ single crystal. It was found that the dislocation is strongly pinned by these obstacles. A 2-nm void is a stronger obstacle than a 2-nm He bubble at low He contents, whereas at the highest He content, five $\mathrm{He}$ atoms per vacancy, the He bubble becomes stronger than the void.

It has been recently suggested that high-density argon bubbles could act as obstacles to dislocation motion leading to hardening [21]. Uniformly distributed Ar bubbles can be considered as a stronger barrier to the motion of dislocation resulting in the hardening in the irradiated P92 steel. In addition, it can be inferred that the hardness increase caused by the formation of $\mathrm{Ar}$ bubbles is stronger than the hardness decrease resulting from annihilation of other irradiation defects [22]. The microstructure examination performed in this study have confirmed that hardening of the irradiated T91MSPD steel gradually increases with an increase in the irradiation dose up to $45 \mathrm{dpa}$ due to the formation of dislocation loops and nano-sized Ar-associeted bubbles.

In general, radiation strengthening is highly dosedependent at low fluences and saturates at doses exceeding the critical value. The critical saturation dose depends on the irradiation temperature, increasing with 
increasing irradiation temperature up to $330{ }^{\circ} \mathrm{C}$, and then decreasing at higher irradiation temperatures [28].

G. Was et al. [2], analyzing data on radiationinduced strengthening of the heats of 304SS and 316SS steels irradiated with protons and neutrons, showed that radiation hardening of austenitic steels reaches saturation at about a few dpa. The same results were revealed at irradiations of a number of austenitic alloys with accelerated ions, and in particular, with argon ions [23-25].

It appears that a similar tendency can be extended to ferritic-martensitic steels. At least, for steels that are in the focus of current study, i.e., T91-MSPD and T91-M, the radiation hardening also tends to saturation at about a few dpa. However, the magnitude of the hardening is almost half compared to austenitic alloys, which indicates a lower probability of embrittlement.

Comparison of the radiation-induced hardening $(\Delta H$, the difference of hardness values of irradiated and unirradiated materials) of ferritic-martensitic steels obtained by different authors [16, 26-33] (Fig. 9) shows some differences in the data, which is probably due, first of all, to the difference in the irradiation temperature. Additionally, a noticeable difference in data is observed for materials with different microstructure. For instance, a clear discrepancy can be seen by comparing alloys with ferrite $(\Delta H=0.95 \mathrm{GPa})$ and tempered martensite $(\Delta H=0.58 \mathrm{GPa})$ structures at low doses of 2 .. $3 \mathrm{dpa}$. At a dose of $30 \mathrm{dpa}$ these values are estimated as 1.32 and $0.85 \mathrm{GPa}$, respectively, $[27,28]$.

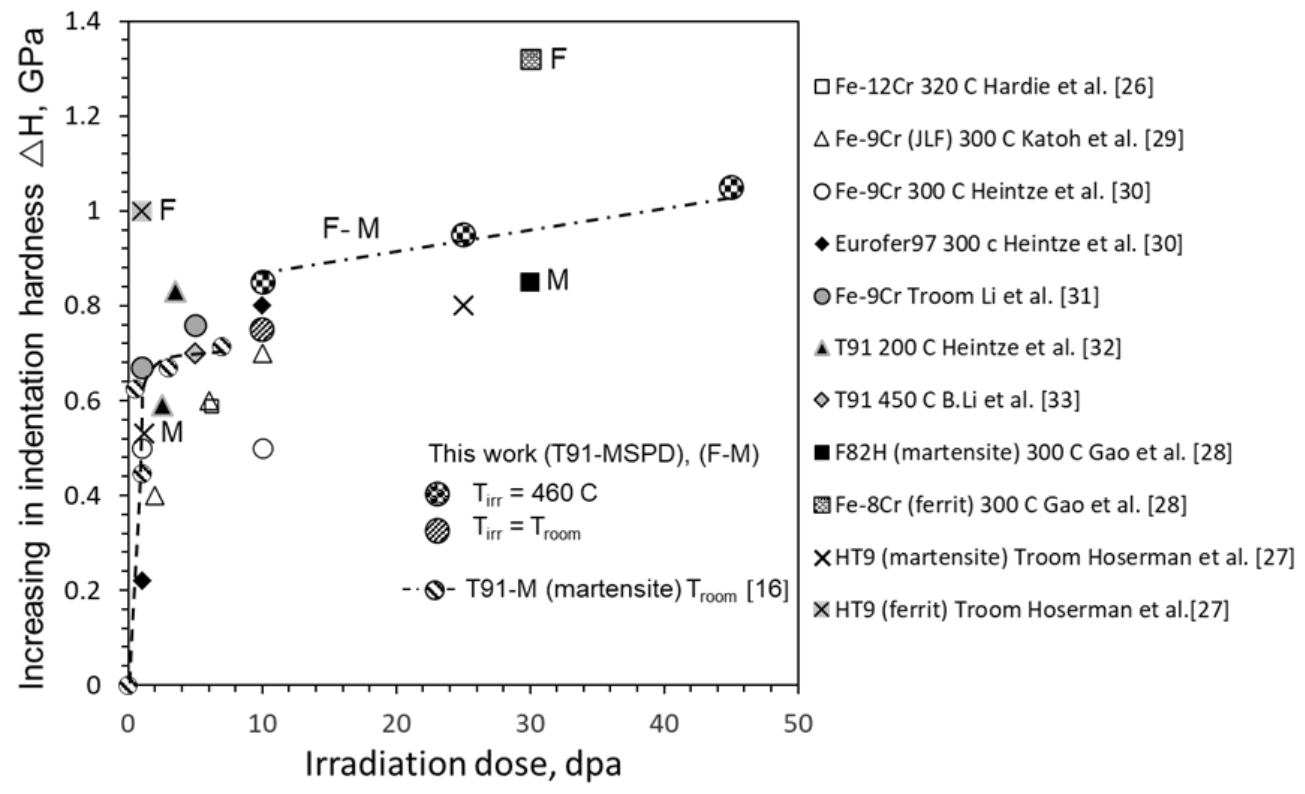

Fig. 9. Relative radiation-induced hardening of ferritic-martensitic steels. Dotted and dash-dotted lines are drawn for eyes only

Clearly, the fine microstructure of tempered martensite has a significant effect on the decrease in hardening under irradiation. The ultra-fine-grained structure of T91-MSPD steel, in turn, has a high density of distribution boundaries, which act as absorbers of radiation defects. For this reason, the formation of obstacles to the movement of dislocations is expected to be impeded in ferritic-martensitic steel with a high density of initial traps/sinks for radiation defects. And, thus, ferritic-martensitic steels are less susceptible to radiation hardening/embrittlement compared to materials with a purely ferritic microstructure (see Fig. 9).

Due to the substantial difference in hardness values of unirradiated samples, a comparison between T91MSPD and T91-M, in terms of irradiation-induced hardening, appears to be the more correct considering the corresponding nanohardness increments described as the ratio of $\triangle H$ and $H_{0}[25,34]$. According to the obtained data, the ratios of hardness are approximately 19 and $24 \%$ in case of irradiations performed at $20{ }^{\circ} \mathrm{C}$ for T91-MSPD and T91-M, respectively, and $22 \%$ for T91-MSPD irradiated at $460{ }^{\circ} \mathrm{C}$. So, the hardening degree of both alloys is nearly equivalent when the irradiation dose is approximately $10 \mathrm{dpa}$. At this dose, the hardening reaches almost saturation or insignificantly increases with the radiation dose.

Although the initial strength and density of sinks are different in T91-M and T91-MSPD steels, it appears that the formation of Ar-associated nano-bubbles in a similar manner influences the hardening behavior of steels under argon-ion irradiation. In addition, the processes of recombination of radiation defects become comparable due to the large number of defects at doses about 10 dpa that predetermines a comparable degree of hardening of both alloys.

\section{CONCLUSIONS}

Ferritic-martensitic steel T91-MSPD with an ultrafine-grained modified structure was irradiated with 1.4 $\mathrm{MeV} \mathrm{Ar}^{+}$ions to doses from 10 to $45 \mathrm{dpa}$ at room temperature and $460{ }^{\circ} \mathrm{C}$. The radiation microstructure and hardening of steel were studied and the following conclusions were drawn:

Observed significant increase (1.3 times) in the hardness of unirradiated samples T91-MSPD is due to grain refinement, crushing of lamellae, a decrease in the 
size of carbides of the MX type and their more uniform distribution.

The hardening of the irradiated steel gradually increases with an increase in the irradiation dose up to 45 dpa due to the formation of dislocation loops and nano-sized Ar-associeted bubbles.

The hardening degree of T91-MSPD and T91-M is nearly equivalent when the irradiation dose is approximately $10 \mathrm{dpa}$.

\section{ACKNOWLEDGEMENTS}

The authors very much appreciated assistance of Dr Marta Serrano (Structural Material Division CIEMAT, Spain) in providing the T91-M material and great interest to this work.

The work was financially supported by the National Academy of Science of Ukraine (program "Support of the development of main lines of scientific investigations" (KPKVK 6541230)).

\section{REFERENCES}

1. S.J. Zinkle, J.T. Busby. Structural materials for fission \& fusion energy // Mat. Today. 2009, v. 12, p. 12-19.

2. G.S. Was et al. Emulation of neutron irradiation effects with protons: validation of principle // J. Nucl. Mater. 2002, v. 300, p. 198-216.

3. В.М. Ажажа, О.В. Чёрный, Г.Е. Сторожилов, Н.Ф. Андриевская, Т.Ю. Рудычева. Изучение деформированного состояния при разнонаправленной обработке $\mathrm{Nb}$-Ті-сплава // Вопросы атомной науки и техники. Серия «Вакуум, чистые материаль, сверхпроводники». 2004, №6(14), с. 136-139.

4. Н.Ф. Андриевская, В.С. Оковит, Т.Ю. Рудычева, М.П. Старолат, Г.Е. Сторожилов, М.А. Тихоновский, П.А. Хаймович, И.Н. Шаповал. Эволюция структуры и свойств сплава НТ-50 при больших пластических деформациях // Физика и техника высоких давлений. 2009, т. 19, №2, с. 136-142.

5. V. Voyevodin, M. Tikhonovsky, G. Tolstolutska, H. Rostova, R. Vasilenko, O. Kalchenko, N. Andrievska, O. Velikodnyi. Structural features and operational characteristics of steel T91 // East Eur. J. Phys. 2020, v. 3, p. 93-98.

6. В.М. Ажажа, О.В. Чёрный, Г.Е. Сторожилов, Н.Ф. Андриевская, Т.Ю. Рудычева. Изучение деформированного состояния при разнонаправленной обработке $\mathrm{Nb}$-Ті-сплава // Вопросы атомной науки и техники. Серия «Вакуум, чистые материаль, сверхпроводники». 2004, №6(14), с. 136-139.

7. G.D. Tolstolutskaya, V.V. Ruzhytskiy, I.E. Kopanetz, V.N. Voyevodin, A.V. Nikitin, S.A. Karpov, A.A. Makienko, T.M. Slusarenko. Accelerating complex for study of helium and hydrogen behavior in conditions of radiation defects generation // Problems of Atomic Science and Technology. Series "Physics of Radiation Effect and Radiation Materials Science". 2010, N 1(65), p. 135-140.

8. G.N. Tolmachova, G.D. Tolstolutskaya, S.A. Karpov, B.S. Sungurov, R.L. Vasilenko. Application of nanoindentation for investigation of radiation damage in SS316 stainless steel // Problems of Atomic Science and Technology. 2015, N 5(99), p. 168-173.
9. W.C. Oliver, G.M. Pharr. An improved technique for determining hardness and elastic modulus using load and displacement sensing indentation experiments // J. Mater. Res. 1992, v. 7, N 6, p. 1564-1583.

10. M.B. Toloczko, F.A. Garner, V.N. Voyevodin, et al. Ion-induced swelling of ODS ferritic alloy MA957 tubing to 500 dpa // J. Nucl. Mater. 2014, v. 453, p. 323-333.

11. R.E. Stoller, M.B. Toloczko, G.S. Was, A.G. Certain, S. Dwaraknath, F.A. Garner. On the use of SRIM for computing radiation damage exposure // Nucl. Instrum. Methods Phys. Res. Sect. B Beam Interact. Mater. Atoms. 2013, v. 310, p. 75-80.

12. R.E. Stoller. Role of cascade energy and temperature in primary defect formation in iron // $J$. Nucl. Mater. 2000, v. 276, p. 22-32.

13. M.J. Norgett, M.T. Robinson, I.M. Torrens. A proposed method of calculating displacement dose rates // Nucl. Eng. Des. 1975, v. 33, p. 50-54.

14. R. Kasada et al. A new approach to evaluate irradiation hardening of ion-irradiated ferritic alloys by nano-indentation techniques // Fusion Eng. Des. 2011, v. 86 , p. $2658-2661$.

15. H.F. Huang, D.H. Li, J.J. Li, R.D. Liu, G.H. Lei. Nanostructure variations and their effects on mechanical strength of $\mathrm{Ni}-17 \mathrm{Mo}-7 \mathrm{Cr}$ alloy under xenon ion irradiation // Mater. Trans. 2014, v. 55, p. 12431247.

16. V.N. Voyevodin, G.D. Tolstolutskaya, S.A. Karpov, M.A. Tikhonovsky, G.N. Tolmachova, A.S. Kalchenko, R.L. Vasilenko, I.E. Kopanets. Effect of argon ion irradiation on hardening and microstructure of ferritic-martensitic steel T91 // Problems of Atomic Science and Technology. Series "Physics of Radiation Effect and Radiation Materials Science”. 2019, N 2(120), p. 7-12.

17. G.M. Pharr, T.Y. Tsui, A. Bolshakov, W.C. Oliver. Effect of Residual Stress on the Measurement of Hardness and Elastic Modulus Using Nanoindentation // Mater. Res. Soc. Symp. Proc. 1994, v. 338, p. 127-134.

18. W. Zhang, H. Han, J. Dai, et al. Simulation of migration and coalescence of helium bubbles in nickel // J. Nucl. Mater. 2019, v. 518, p. 48-53.

19. M. Klinger. More features, more tools, more CrysTBox // Journal of Applied Crystallography. 2017, v. 50, p. 1226-1234.

20. S.M. Hafez Haghighat and R. Schäublin. Influence of the stress field due to pressurized nanometric He bubbles on the mobility of an edge dislocation in iron // Phil. Mag. 2010, v. 90, p. 1075-1100.

21. Y.N. Osetsky, Roger E. Stoller. Atomic-scale mechanisms of helium bubble hardening in iron // $J$. Nucl. Mater. 2015, v. 465, p. 448-454.

22. Q. Li, Y. Shen, J. Zhu, Xi Huang, and Zh. Shang. Evaluation of Irradiation Hardening of P92 Steel under Ar Ion Irradiation // Metals. 2018, v. 8, p. 94; doi:10.3390/met8020094.

23. S.A. Karpov, G.D. Tolstolutskaya, B.S. Sungurov, A.Yu. Rostova, G.N. Tolmacheva, I.E. Kopanets. Hardening of SS316 Stainless Steel Caused by the Irradiation with Argon Ions // Materials Science. 2016, v. 52 , issue 3 , p. 377-384. 
24. V.N. Voyevodin, S.A. Karpov, G.D. Tolstolutskaya, M.A. Tikhonovsky, A.N. Velikodnyi, I.E. Kopanets, G.N. Tolmachova, A.S. Kalchenko, R.L. Vasilenko, I.V. Kolodiy. Effect of irradiation on microstructure and hardening of $\mathrm{Cr}-\mathrm{Fe}-\mathrm{Ni}-\mathrm{Mn}$ highentropy alloy and its strengthened version // Phil. Mag. 2020, v. 100, N 7, p. 822-836.

25. Zh. Zhu, H. Huang, J. Liu, Jie Gao, Zh. Zhu. Xenon ion irradiation induced hardening in inconel 617 containing experiment and numerical calculation // $J$. Nucl. Mater. 2019, v. 525, p. 32-39.

26. C.D. Hardie, S.G. Roberts, and A.J. Bushby. Understanding the effects of ion irradiation using nanoindentation techniques // J. Nucl. Mater. 2015, v. 462, p. 391-401.

27. P. Hosemann, C. Vieh, R.R. Greco, S. Kabra, J.A. Valdez, M.J. Cappiello, S.A. Maloy. Nanoindentation of ion irradiated steels // J. Nucl. Mater. 2009, v. 389, p. 239-247.

28. J. Gao, K. Yabuuchi, A. Kimura. Ionirradiation hardening and microstructural evolution in F82H and ferritic alloys // J. Nucl. Mater. 2019, v. 515, p. 294-302.

29. Y. Katoh, M. Ando, A. Kohyama. Radiation and helium effects on microstructures, nano-indentation properties and deformation behavior in ferrous alloys // J. Nucl. Mater. 2003, v. 323, p. 251-262.

30. C. Heintze, C. Recknagel, F. Bergner, M. Hernandez-Mayoral, A. Kolitsch. Ion irradiation-induced damage of steels characterized by means of nanoindentation // Nucl. Instrum. Methods in Phys. Res. B. 2009, v. 267, p. 1505-1508.

31. S. Li, Y. Wang, X. Dai, F. Liu, J. Li, X. Wang. Evaluation of hardening behaviors in ion-irradiated $\mathrm{Fe}$ $9 \mathrm{Cr}$ and $\mathrm{Fe}-20 \mathrm{Cr}$ alloys by nanoindentation technique // J. Nucl. Mater. 2016, v. 478, p. 50-55.

32. C. Heintze, F. Bergner, S. Akhmadaliev, E. Altstadt. Ion irradiation combined with nanoindentation as a screening test procedure for irradiation hardening // J. Nucl. Mater. 2016, v. 472, p. 196-205.

33. B. Li et al. Evaluation of helium effect on irradiation hardening in F82H, ODS, SIMP and T91 steels by nano-indentation method // Fusion Engineering and Design. 2019, v. 142, p. 6-12.

34. K. Vogel, C. Heintze, P. Chekhonin, S. Akhmadaliev, E. Altstadt, F. Bergner. Relationships between depth-resolved primary radiation damage, irradiation-induced nanostructure and nanoindentation response of ion-irradiated $\mathrm{Fe}-\mathrm{Cr}$ and ODS $\mathrm{Fe}-\mathrm{Cr}$ alloys // Nuclear Materials and Energy. 2020, v. 24, p. 100759.

Статья поступила в редакциию 25.02.2021 2.

\title{
ВЛИЯНИЕ ИНТЕНСИВНОЙ ПЛАСТИЧЕСКОЙ ДЕФОРМАЦИИ НА РАДИАЦИОННОЕ УПРОЧНЕНИЕ ФЕРРИТНО-МАРТЕНСИТНОЙ СТАЛИ Т91
}

\author{
В.Н. Воеводин, Г.Д. Толстолуцкая, С.А. Карпов, А.Н. Великодный, М.А. Тихоновский,
} А.С. Кальченко, Г.Н. Толмачева, Р.Л. Василенко, И.Е. Копанеи,

Изучено влияние термомеханической обработки на радиационное упрочнение ферритно-мартенситной стали Т91. Использование интенсивной пластической деформации (ИПД) методом «осадки-экструзии» с последующей термообработкой привело к значительному измельчению зерна, дроблению ламелей распределенного мартенсита, уменьшению размеров карбидов типа МX и более равномерному их распределению. Измерение нанотвердости ИПД модифицированной стали показало увеличение твердости в 1,4 раза по сравнению с исходной сталью. Радиационную стойкость модифицированной стали исследовали после облучения ионами $\mathrm{Ar}^{+}$с энергией $1,4 \mathrm{MэB} \mathrm{в} \mathrm{диапазоне} \mathrm{доз} 10 \ldots 45$ смещений на атом (сна) при комнатной температуре и $460{ }^{\circ} \mathrm{C}$. Изучение микроструктуры выполнялось с помощью просвечивающей электронной микроскопии (ПЭМ). Обнаружено, что дислокационные петли и наноразмерные пузырьки аргона преобладают в микроструктуре повреждений после ионного облучения. Обсуждаются влияния индуцированных ИПД-превращений, а также нанопузырьков аргона на упрочнение, наблюдаемое в облученной стали.

\section{ВПЛИВ ІНТЕНСИВНОЇ ПЛАСТИЧНОЇ ДЕФОРМАЦІЇ НА РАДІАЦИЙНЕ ЗМНЦЕННЯ ФЕРИТНО-МАРТЕНСИТНОЇ СТАЛІ Т91}

\section{В.М. Восводін, Г.Д. Толстолуцька, С.О. Карпов, О.М. Великодний, М.А. Тихоновський, О.С. Кальченко, Г.М. Толмачова, Р.Л. Василенко, І.С. Копанець}

Вивчено вплив термомеханічної обробки на радіаційне зміцнення феритно-мартенситної сталі Т91. Використання інтенсивної пластичної деформації (ІПД) методом «осаджування-видавлювання» 3 подальшою термообробкою призвело до значного подрібнення зерна, дроблення ламелей розподіленого мартенситу, зменшення розмірів карбідів типу МX і більш рівномірному їх розподілу. Вимірювання нанотвердості ІПД модифікованої сталі показало збільшення твердості в 1,4 рази в порівнянні 3 вихідною сталлю. Радіаційну стійкість модифікованої сталі досліджували після опромінення іонами $\mathrm{Ar}^{+} 3$ енергією $1,4 \mathrm{MeB}$ у діапазоні доз $10 \ldots 45$ зсувів на атом (зна) при кімнатній температурі і $460{ }^{\circ} \mathrm{C}$. Вивчення мікроструктури виконувалося за допомогою просвічувальної електронної мікроскопії (ПЕМ). Виявлено, що дислокаційні петлі і нанорозмірні бульбашки аргону переважають у мікроструктурі пошкоджень після іонного опромінення. Обговорюються впливи індукованих ІПД-перетворень, а також нанобульбашок аргону на зміцнення, що спостерігається в опроміненій сталі. 